\title{
Recent outbreaks of Rift Valley fever in East Africa and the Middle East
}

\author{
Yousif E. Himeidan ${ }^{1,2 *}$, Eliningaya J. Kweka ${ }^{3,4}$, Mostafa M. Mahgoub ${ }^{5}$, El Amin El Rayah ${ }^{6}$ and \\ Johnson O. Ouma ${ }^{2,7}$
}

1 Entomology Unit, Faculty of Agriculture and Natural Resources, University of Kassala, New Halfa, Sudan

2 Africa Technical Research Centre, Vector Health International, Arusha, Tanzania

${ }^{3}$ Division of Livestock and Human Diseases Vector Control, Tropical Pesticides Research Institute, Arusha, Tanzania

${ }^{4}$ Department of Medical Parasitology and Entomology, Catholic University of Health and Allied Sciences, Mwanza, Tanzania

${ }^{5}$ Blue Nile National Institute for Communicable Diseases, University of Gezira, Madani, Sudan

${ }^{6}$ Department of Zoology, University of Khartoum, Khartoum, Sudan

${ }^{7}$ Biotechnology Research Institute, Kenya Agricultural and Livestock Research Organization, Kikuyu, Kenya

\section{Edited by:}

Juan-Carlos Navarro, Universidad

Central de Venezuela, Venezuela

\section{Reviewed by:}

Tetsuro Ikegami, University of Texas

Medical Branch, USA

Jordi Figuerola, Estacion Biologica de

Doñana-CSIC, Spain

\section{*Correspondence}

Yousif E. Himeidan, Vector Health International, Africa Technical

Research Centre, Vector Control Unit, Dodoma Road, P.O. Box 15500,

Arusha, Tanzania

e-mail:yousif@vectorhealth.com
Rift Valley fever (RVF) is an important neglected, emerging, mosquito-borne disease with severe negative impact on human and animal health. Mosquitoes in the Aedes genus have been considered as the reservoir, as well as vectors, since their transovarially infected eggs withstand desiccation and larvae hatch when in contact with water. However, different mosquito species serve as epizootic/epidemic vectors of RVF, creating a complex epidemiologic pattern in East Africa. The recent RVF outbreaks in Somalia (2006-2007), Kenya (2006-2007), Tanzania (2007), and Sudan (2007-2008) showed extension to districts, which were not involved before. These outbreaks also demonstrated the changing epidemiology of the disease from being originally associated with livestock, to a seemingly highly virulent form infecting humans and causing considerably high-fatality rates. The amount of rainfall is considered to be the main factor initiating RVF outbreaks. The interaction between rainfall and local environment, i.e., type of soil, livestock, and human determine the space-time clustering of RVF outbreaks. Contact with animals or their products was the most dominant risk factor to transfer the infection to humans. Uncontrolled movement of livestock during an outbreak is responsible for introducing RVF to new areas. For example, the virus that caused the Saudi Arabia outbreak in 2000 was found to be the same strain that caused the 1997-98 outbreaks in East Africa. A strategy that involves active surveillance with effective case management and diagnosis for humans and identifying target areas for animal vaccination, restriction on animal movements outside the affected areas, identifying breeding sites, and targeted intensive mosquito control programs has been shown to succeed in limiting the effect of RVF outbreak and curb the spread of the disease from the onset.

Keywords: RVFV outbreaks, Aedes mosquitoes, rainfall, East Africa

\section{INTRODUCTION}

Rift Valley fever (RVF) is an important neglected, emerging, mosquito-borne disease with severe negative economic impact as it affects human and animal health. The disease is caused by RVF virus (RVFV) an acute febrile arbovirus in the Phlebovirus genus and Bunyaviridae family. The disease was first characterized by Daubney et al. (1) while working at the Veterinary Research Laboratory at Kabete in Kenya. An earlier report by Stordy (2) had described a similar disease syndrome, which may well have been RVF, it was described as an acute and highly fatal disease in the Rift Valley in exotic wool sheep, which had been imported into East Africa from Europe $(1,3)$. These European stock species were more severely affected than native African stock. The disease remained a veterinary concern in East Africa until a major outbreak occurred in Egypt in 1977. A second outbreak outside East Africa occurred in 2000 when RVF moved into Saudi Arabia and
Yemen in the Arabian Peninsula (4). This was the first time the disease was being detected outside of Africa - where it had been confined so far - becoming a threat to the Middle East.

From the most recent outbreaks that occurred in Kenya, Somalia, Tanzania in $2007(5,6)$, and Sudan in 2008 and $2010(7,8)$, RVF appears to have great potential for spreading into new areas and with huge impact on human and animal health. This calls for an integrated approach between different governmental sectors and organizations within and between countries and regions to address both human and animal health. Limited information is available on the evolution of RVF between East Africa and Middle East. In order to highlight the urgent need of establishing a health system for controlling RVF in the region, this review article aims to gather experiences and highlight basic information on the ecological aspects, epidemiological, and risk factors associated with the distribution of recent outbreaks in East Africa and Middle East. 


\section{TRANSMISSION AND IMPACT}

The virus is known to infect a range of animal hosts including sheep, cattle, goats, camels, buffaloes, and others. The incubation period in animals is between 1 and 6 days in general, 1 and 3 days in sheep, and only about 12 and $36 \mathrm{~h}$ in lambs (9). Sheep and to a lesser extent cattle were the principle disease hosts in both East and southern Africa (3). Sheep seemed to be the most susceptible animal as it was noted that RVF caused high rates of abortions during pregnancy and high mortalities among newborns $(10,11)$. Lambs can die before they acquire passive immunity and mortality and abortion rates among old sheep range from 5 to $100 \%$ (9). Infections can therefore cause severe disease and result in significant economic losses. For example, the 2007 outbreak was the most widespread affecting livestock in 11 regions in Tanzania and Kenya. A total of 16,973 cattle, 20,193 goats, and 12,124 sheep died of the disease, with spontaneous abortions reported in 15,726 cattle, 19,199 goats, and 11,085 sheep $(12,13)$. Considering the wide-ranging impacts of the disease on the livestock sector and other segments of the economy, the 2007 RVF outbreak in Kenya alone induced losses of over Ksh 2.1 billion (US\$32 million) on the Kenyan economy (14). The overall economic loss in East Africa is estimated to exceed $\$ 60$ million because of disruption in trade from these recent epizootics between 2006 and 2007 (15). In Saudi Arabia, during the outbreak of 2000, it was estimated that around 40,000 animals including sheep, goats, camels, and cattle died whereas 8,000-10,000 of them aborted (16). The outbreaks of 2007 in Sudan led to bans in livestock trade between Saudi Arabia and Sudan, resulting in vast economic impact on the animal market in the two countries (17).

Infection by RVF usually spreads among livestock first through mosquitoes bites. In addition, the infection can also be transmitted vertically between animals (18) (Figure 1). From domestic animals, the virus is transmitted to humans mainly through direct contact with blood, excreta, meat, or secretions of infected animals, consumption of raw milk (19-21), and in few cases, transmission through mosquito bites that belong to the genera Anopheles, Aedes, and Culex seems to occur $(22,23)$ (Figure 1). Symptoms of RVF in humans vary from a flu-like syndrome to encephalitic, ocular, or hemorrhagic syndrome. The case fatality rate of the hemorrhagic syndrome form can be as high as $50 \%$ (24). The most severe outbreaks of 1997-1998 and 2006-2007 in Tanzania, Kenya, and Somalia caused 478 human deaths in 1998 and 309 in 2007 (25-27). The outbreak of 2000 resulted in 883 human cases with 124 deaths (case fatality rate, 14\%) in Saudi Arabia (28) and 1,328 human cases, with 166 deaths in neighboring north western Yemen (29-31). In Sudan, the outbreak of 2007 resulted in 698 cases, including 222 deaths $(32,33)$.

\section{MOSOUITO VECTORS}

Mosquitoes in the Aedes genus have been considered the primary maintenance host and source of RVFV that initiate disease outbreaks $(34,35)$. RVFV is known to be carried in the eggs of Aedes mosquitoes, which can survive for several years in the dried mud (36). On flooding, Aedes mosquito species play an important role in initiation of infection and virus circulation. The survival of RVFV during inter epizootics was believed to depend on transovarial transmission of the virus in flood water by Aedes mosquitoes (37). Other mosquitoes in the Culex and
Anopheles genus are thought to be important in amplification of virus activity during outbreaks. The virus has also been detected in phlebotomine sand flies, Culicoides midges, and Amblyomma tick species although these infections are thought not to play an important role in the life cycle of the virus or in disease outbreak settings (38-42). In the laboratory, the RVFV was also transmitted trophically or mechanically by other hematophagous flies but field relevance of these transmission routes are still unclear $(43,44)$.

The important RVF vectors in East Africa include Aedes mcintoshi, Aedes ochraeus, Culex pipiens, Aedes dalzieli, and Aedes vexans (45). Records also indicated that A. mcintoshi is the main vector for RVF in Kenya $(41,42,46)$. Investigation on RVFV by reverse transcription-polymerase chain reaction (RT-PCR) during the recent outbreak of 2006/2007 in Kenya showed that 77 out of 3,003 pools representing 10 species, from 4 affected districts, tested positive for RVFV, including A. mcintoshi/circumluteolus (26 pools), Aedes ochraceus (23 pools), Mansonia uniformis (15 pools); Cx. poicilipes, Culex bitaeniorhynchus (3 pools each); Anopheles squamosus, Mansonia africana (2 pools each); Culex quinquefasciatus, Culex univittatus, Aedes pembaensis (1 pool each). A. pembaensis, $C x$. univittatus, and $C x$. bitaeniorhynchus were for the first time observed positive for the virus (42). The observation of infected A. ochraceus in Garissa, Kenya, represents a new RVFV-vector association in East Africa. A. ochraceus is a known vector of RVFV in West Africa (39), along with A. vexans arabiensis and A. dalzieli. A. vexans arabiensis is also a vector of RVFV in Saudi Arabia (40, 44) and although the species has not been documented in Kenya, it has been found in neighboring Somalia and Sudan $(47,48)$ (Table 1).

It has been suggested that different mosquito species serve as epizootic/epidemic vectors of RVFV in diverse ecologies, creating a complex epidemiological pattern in East Africa (42). A. aegypti has been found naturally infected with RVFV and seemed to be the main source of the infection during the outbreak of 2007 in Sudan. During this outbreak, RVFV was successfully detected by RT-PCR in larvae, male and females of An. arabiensis, An. coustani, Cx. pipiens complex, Cx. poicilipes, and A. aegypti (Table 1). The infections were considered as a precursor for viral circulation in these species (incriminated in dissemination or acquired the virus in its mid gut only) (21). The detection of RVFV in male and larval stages indicated transovarial (vertical) transmission of the virus within these mosquito species. It may also show possible venereal RVFV transmission when a male is infected vertically and then infects the female during mating (21).

Laboratory established colonies of A. aegypti from Tahiti exhibited the highest infection rates of RVFV when compared with other potential vectors in the Mediterranean region (56). A. aegypti has also demonstrated infection and transmission rates of the nonstructural proteins (NSs) deletion virus similar to wild-type virus, but dissemination rates were significantly reduced (35). Cx. pipiens was incriminated as the main RVF vector in Egypt based on field isolates and also in Maghreb and South Africa based on laboratory experiments (57-59).

\section{OCCURRENCE OF RVF OUTBREAKS}

The RVF has demonstrated capacity for emerging in new territories or for re-emerging after long periods of silence. Since the 


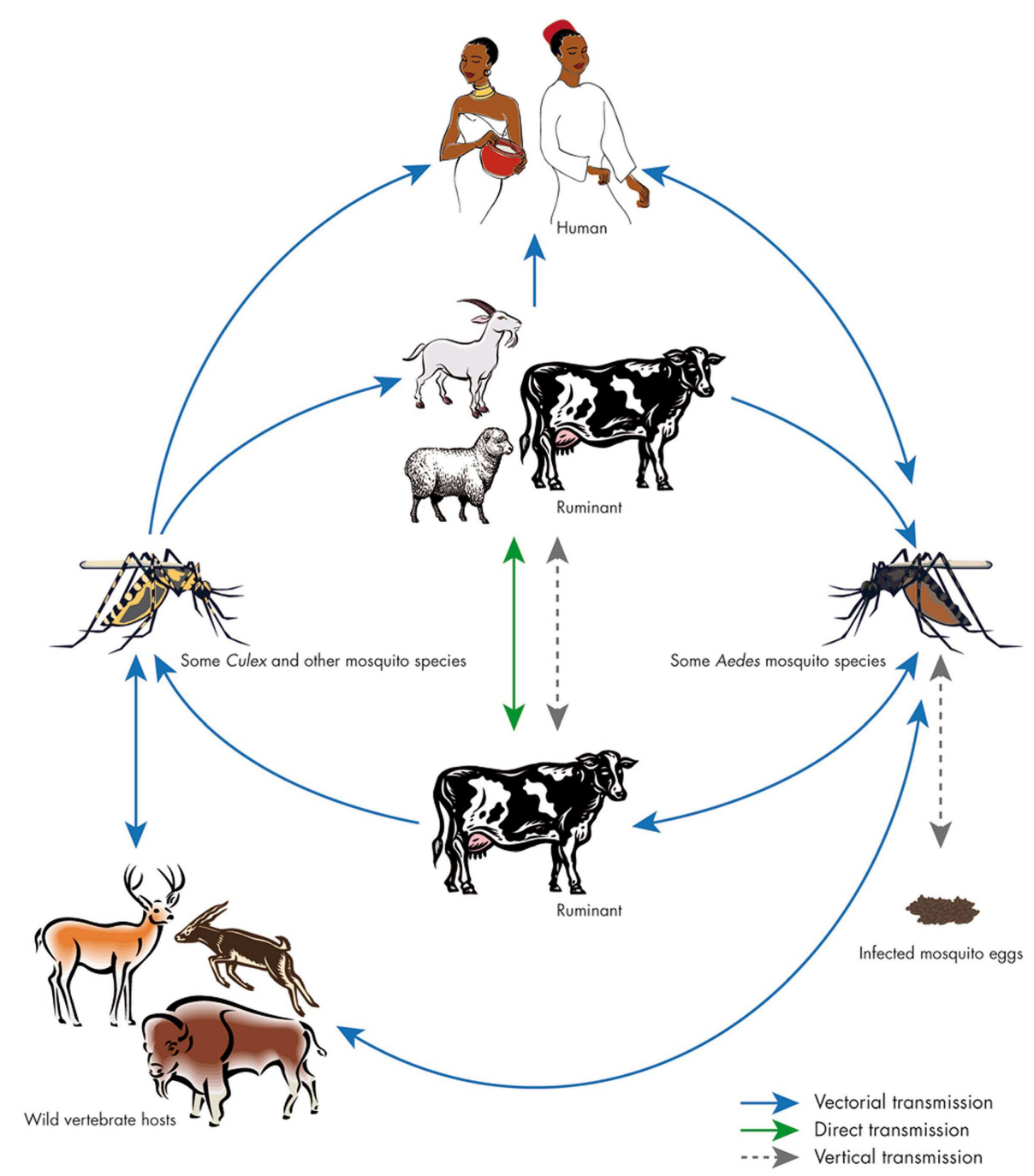

FIGURE 1 | Cycle of Rift Valley fever. The virus can be maintained in an enzootic cycle involving Aedes mosquitoes, which are able to transmit the virus vertically to their offspring. Epizootic outbreaks are often linked with unusual rains or warm seasons, favoring the hatching of infected Aedes eggs that are then able to initiate the virus circulation.

Subsequently, large numbers of secondary vectors belonging to the
Culex genus could be infected and induce the emergence of epidemic/epizootic outbreaks. Transmission to humans occurs through direct contact with high-virus loads when aborted fetuses are manipulated. Source: Balenghien et al. (34), with permission from Thomas Balenghien, CIRAD, UMR Contrôle des maladies, F-34398 Montpellier, France. first outbreak in 1915, epizootics occurred periodically in Kenya until the disease was recognized in South Africa in 1951 (60), when humans became ill after handling dead and infected animals (3). Further, RVF outbreaks have been confirmed in most sub-Saharan countries (61) moving through the Rift Valley from Kenya to Tanzania, Zimbabwe, Zambia, and subsequently, RVF outbreak was first recorded in 1987 in West Africa in Senegal and Mauritania (3). RVF spread northwards through the Nile Valley into Southern Sudan and to White Nile state in Sudan where the first outbreak was identified in 1973. The disease then spread among other neighboring states within the country (Figure 2) and up to the Egyptian delta where a major epidemic with 20,000-200,000 clinical illnesses and 600 deaths was reported in 1977 (3, 62, 63). The disease also spread from continental Africa to Madagascar in 1991 (64-67) and to the Arabian Peninsula in Saudi Arabia and Yemen in 2000 (4). The recent RVF outbreaks in East Africa in Somalia (20062007) (5), Kenya (2006-2007) (6), Tanzania (2007) (5), and Sudan (2007-2008) (7) showed the changing epidemiology of the disease from being originally associated with livestock to infecting humans considerably and resulting in high-fatality rates (7).

Sindato and others investigated the spatial and temporal pattern of RVF outbreaks in Tanzania over the past 80 years (68). All RVF outbreaks reported during 1930-2007 were found to occur between December and June. Expansion of the disease into new geographical areas from the original documented outbreaks was observed. For example, between 1930 and 1957 only $<1 \%$ of the districts in Tanzania were repeatedly involved in the outbreaks (Figure 3). The 1977-1978 outbreak wave had involved 3.33\% 
Table 1 | Mosquito species incriminated in the transmission of RVFV during the outbreaks recorded in East Africa and the Middle East.

\begin{tabular}{|c|c|c|c|}
\hline $\begin{array}{l}\text { Year of } \\
\text { outbreak }\end{array}$ & $\begin{array}{l}\text { Affected } \\
\text { country }\end{array}$ & Collected mosquitoes & Reference \\
\hline $\begin{array}{l}\text { 1997-1998 } \\
\text { and } 2006\end{array}$ & Kenya & $\begin{array}{l}\text { Culex zombaensis, Culex } \\
\text { poicilipes, Culex } \\
\text { bitaeniorhynchus, Culex } \\
\text { quinquefasciatus, Culex } \\
\text { univittatus, Anopheles } \\
\text { coustani, Anopheles } \\
\text { squamosus, Aedes } \\
\text { mcintoshi, Aedes } \\
\text { ochraceus, Aedes } \\
\text { pembaensis Mansonia } \\
\text { africana, M. uniformis }\end{array}$ & $(42,49)$ \\
\hline
\end{tabular}

\begin{tabular}{|c|c|c|c|}
\hline $\begin{array}{l}\text { 1997-1998 } \\
\text { and } 2007\end{array}$ & Tanzania & Aedes mcintoshi & (6) \\
\hline 1997-1998 & Eastern Africa & Culex theileri & $(50)$ \\
\hline 1977 & Egypt & Culex pipiens & $(51,52)$ \\
\hline 2000 & $\begin{array}{l}\text { Kingdom Saudi } \\
\text { Arabia }\end{array}$ & $\begin{array}{l}\text { Culex pipiens, Aedes } \\
\text { vexans arabiensis, Ae. } \\
\text { Vittatus, Ae. (Stegomyia) } \\
\text { nilineatus, Aedes vexans } \\
\text { arabiensis, and Culex } \\
\text { triteniorynchus }\end{array}$ & $\begin{array}{l}(30,40 \\
53-55)\end{array}$ \\
\hline
\end{tabular}

2000

Yemen

Not defined

$(30,54,55)$

2007-2008

Sudan

Cx pipiens, $C x$.

$(5,21,49)$

Poicilipes, An. arabiensis,

An. coustani, Ae. aegypti

1997-1998 and

Not defined

(6) reservoir, as well as vectors, since their transovarially infected eggs withstand desiccation and larvae emerge when the eggs get into contact with water $(37,73)$. Transovarial transmission is assumed as the mechanism of virus persistence between epizootic events. After flooding, the infected Aedes mosquito eggs will hatch in the persisting water collections, and develop into infective adult mosquitoes. A study in the Ferlo region of Senegal in 2003 observed that when the rainy season began with heavy rains, the temporary ponds that serve as the breeding sites for mosquitoes were flooded to their maximum level immediately. As a result, A. vexans arabiensis populations were found to be abundant at the very beginning of the season, when the majority of eggs in quiescence were flooded (74). The effect of flood water on Aedes breeding habitats has also been studied artificially in central Kenya by sequentially flooding such habitats to determine the numbers of mosquito eggs hatching during each flooding. The authors documented that approximately $90 \%$ of the larvae sampled during four flooding events emerged during the initial one (75). This probably explains why excessive rainfall can result in high density of initial infected population. This hypothesis was supported by the study from Senegal, which found that female mosquitoes hatching from eggs laid during the previous year quickly laid eggs on the pond's wet soil (74). The study also observed that during rainless periods lasting longer than 7 days, the time needed for embryogenesis, these new eggs undergo dormancy as the water level goes down. Once, the rains fall again, large numbers of new eggs hatch resulting into an increase in population, and thereby suggesting that several generations of infected adults can exist during the same rainy season. This dynamic has been seen to also maximize the virus' chance to persist from one year to another in high-stock population, thus, facilitating endemisation of RVFV that is then amplified through feeding of infected adult female mosquitoes on wild and domestic ungulates and may reach epizootic and epidemic dimensions $(42,74)$.

This dynamic can be observed from the 2007 RVF outbreak in Gezira State, Sudan (Figure 5), when satellite monitoring (JuneSeptember, 2007) showed that most of the central Sudan could be unusually subjected to heavy rainfall (76). Accordingly, a RVF risk warning has been generated for central and southern Sudan. Indeed, the predicted unusually heavy rains occurred during JulyAugust and resulted in severe floods (77). In September, suspected human RVF cases were reported (78). The first cases appeared in southern areas of Algabalain locality in White Nile state. The first symptoms among the suspected cases were hemorrhage and fever with rapid death. All reported cases in the beginning of the outbreak were scattered and did not reach any health facilities (21). First human index case was confirmed on 8-14 October, 2007 (76). The RVF outbreak in Sudan came to public attention on October 18,2007 when the Federal Ministry of Health (FMoH) Sudan asked the WHO to assist in the investigation and control of a suspected hemorrhagic fever. The WHO and FMoH teams started investigations in the White Nile state, central Sudan, on October 24, and on the basis of initial results, an outbreak of RVF was declared on October 28, and more help was requested for control measures (79). An announcement was made regarding RVF in animals (80) when the outbreak reached its peak in humans by early November (Figure 5). At the end of the outbreak as of late December 2007 


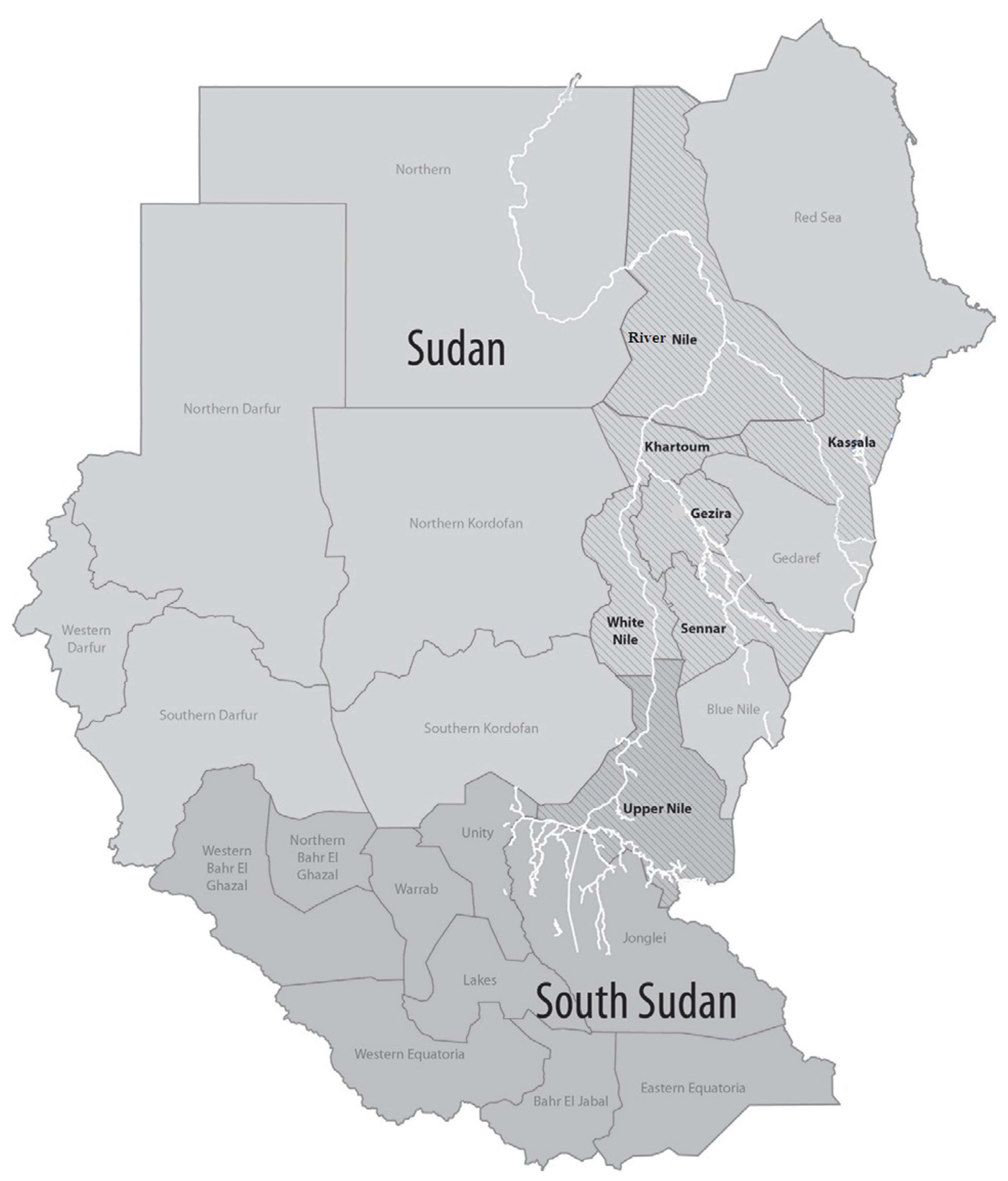

FIGURE 2 | Sudan map shows states with confirmed Rift Valley fever cases are in boldface during 2007 and 2010 outbreaks. Source: Aradaib et al. (8), with permission from Stuart T. Nichol, Centers for Disease Control and Prevention, Atlanta, GA, USA.

to January 2008, a cumulative total of 698 cases, including 222 deaths, was reported from six states (Gezira, Kassala, Khartoum, River Nile, Sennar, and White Nile), yielding an overall CFR of $31.8 \%$. This RVF outbreak was the first one reported in humans and connected directly to heavy rainfall, flooding, and increase in mosquito breeding sites in Sudan (81).

The RVF outbreak of 2007 in Sudan not only validated the association between abnormal rainfall and RVF outbreak but also prediction of RVF outbreak and early warning signs from satellite monitoring. This also showed that the wave of RVF outbreak is likely to end as the water pools due to rainfall and warm temperatures faded-out (68). This is indeed the case as there is only one short-rainy season in Sudan, which ends in October and then the winter season begins at the end of November and runs up to late February. The presumed link between extraordinary flooding events and RVF outbreaks was also well validated, among others, by a successful prediction of the 2007 outbreak in Somalia, Kenya, and northern Tanzania, using climate modeling (82). In fact, each of the seven documented moderate or large RVF outbreaks that have occurred in East Africa over the last 60 years have been associated with El Niño Southern Oscillation (ENSO) associated with above normal and widespread rainfall (83). This association of RVF with 


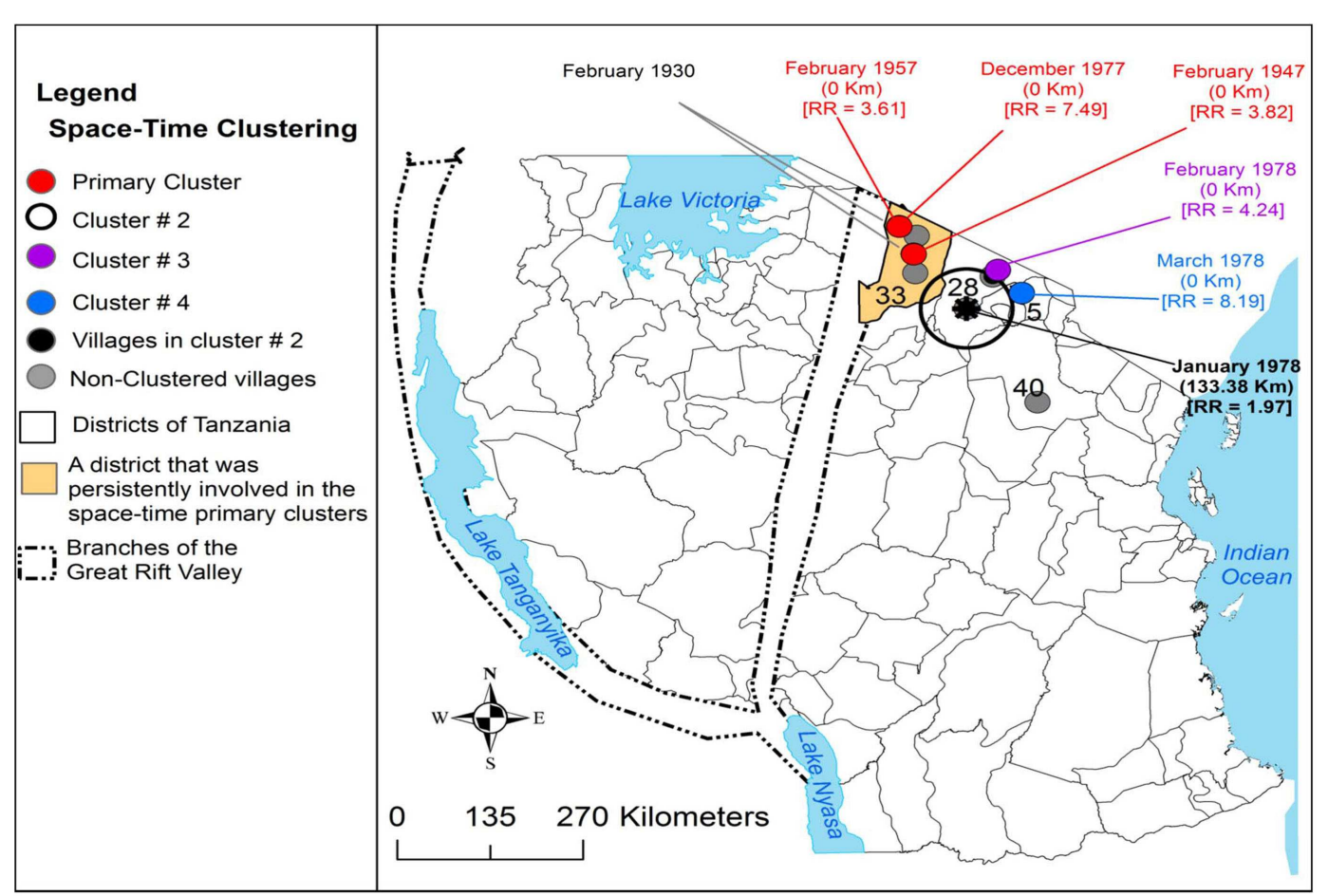

FIGURE 3 | Distribution of village-level space-time clusters of RVF cases from 1947 to 1978. The authors set model parameters for maximum spatial and temporal window sizes and that such cluster could include a maximum of $50 \%$ of all cases. They indicated there were no clusters detected in 1930, from 1947 to 1978 three primary clusters were persistently detected in
Ngorongoro district, each involving one village. An asterisk represents the center of cluster that involved more than one village; relative risk for each cluster is displayed (RR) along with the buffer (circle) size in kilometers (km). Source: Sindato et al. (68), with permission from Calvin Sindato, National Institute for Medical Research, Tabora, Tanzania. excessive rainfall and flooding was also observed in other countries outside the African continent in Arabian Peninsula, i.e., the outbreak of 2000 in Yemen (84).

Interestingly, all RVF outbreaks in Sudan originated in White Nile State where the first RVFV was identified in 1973 as the cause of an extensive epizootic (10), then moved northward through the White Nile river valley to Khartoum in 1976 (85) and extended to the neighboring states of Gezira, Sennar, and Kassla states during 2007 outbreak (Figure 1). In the White Nile State, the river Nile has a very wide basin, which floods annually between June and September, resulting in wide wetland along the valley of the river from the border of Southern Sudan up to Khartoum. It is important to mention that the five states are located in the Central Clay Plain soil of the Sudan, which extends from west of Kassala through Gezira, Khartoum, White Nile up to southern Kurdufan. This type of soil and topography when flooded create large shallow wetlands similar to what is known as "dambo," which is often shown as suitable breeding habitats for Aedes mosquitoes in central, southern, and eastern Africa. This suggested that local environment is very important and is directly linked to RVF outbreak. Significant association was observed between RVF outbreaks from 1930 to 2007 and clay and loam soil textures in the eastern Rift Valley ecosystem of Tanzania where clustering of RVF outbreaks were persistently and predominantly detected (68). Clay soil rather than sandy soil texture supports long-period retention of water contributing to flooding and wetness of habitat suitable for breeding and survival of Aedes mosquito vectors. This suggests that while rainfall might be the major determinant for the onset and switch-off of an outbreak, it is unlikely that it is the only factor responsible for the spread and clustering of RVF cases. A causal association between local environmental factors, livestock density and movement, encroachment of mosquitoes into new areas, and occurrence of RVF has been suggested in previous studies $(20,86,87)$.

\section{RISK FACTORS DURING RVF OUTBREAK}

It is generally accepted that during the 2007 outbreak in Sudan, animal contact was the most dominant risk factor followed by animal products and mosquito bites (78). This is supported by the fact that the 2010 outbreak was first characterized by abortions in ewes followed by infections in persons with histories of contact with aborted fetal material (8). Contact with RVFV-infected animals such as consuming or handling products from sick animals, touching an aborted animal fetus, or being a herdsperson has been documented as the most important risk factor for severe infection during the 2007 outbreak in Kenya (76). A similar result was observed during the previous RVF outbreak of 1997-1998 in northern Kenya (11). These findings are consistent with those from another study from Sudan stating that most of the animals such as sheep, cattle, goats, and camels stay very close to their owners' houses at night $(21,88)$. 


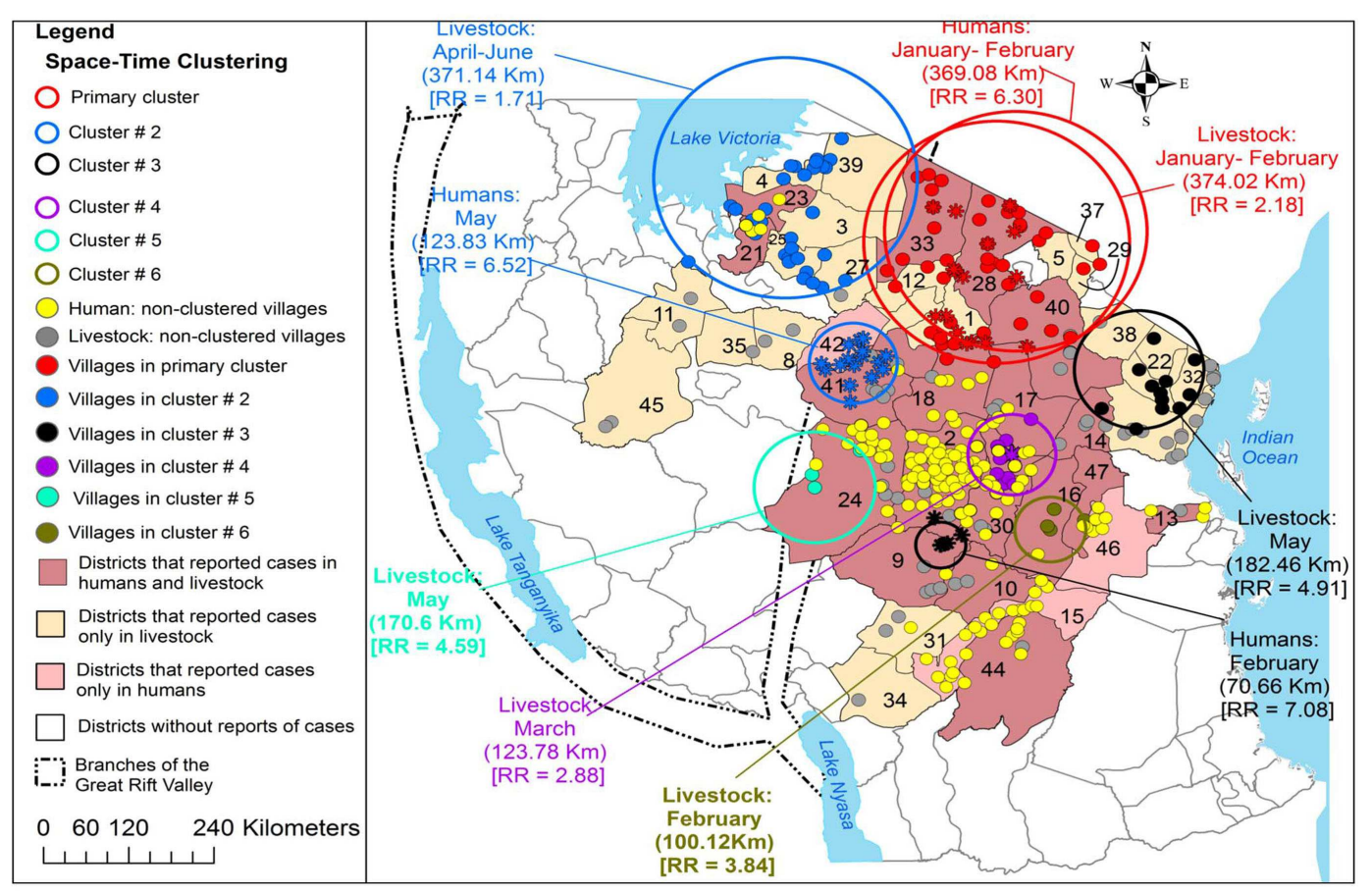

FIGURE 4 | Distribution of village-level space-time clusters of RVF cases in humans and domestic ruminants. The authors set model parameters for maximum spatial and temporal window sizes and that such cluster could include a maximum of $50 \%$ of all cases. They conducted the analysis of clustering of cases separately for humans and domestic ruminants during the 2006/2007 outbreak wave. Between
January and February 2007, there was an overlap of livestock and human primary clusters in the same location. Asterisks correspond to villages that were included within human space-time clusters; relative risk for each cluster is displayed (RR) along with the buffer (circle) size in kilometers $(\mathrm{km})$. Source: Sindato et al. (68), with permission from Calvin Sindato, National Institute for Medical Research, Tabora, Tanzania.
Despite the fact that there was no evidence for horizontal transmission between humans in Sudan or elsewhere, risk from infected pregnant women through vertical transmission can occur. During the 2007 outbreak in Sudan, a 29-year-old pregnant woman presented in early labor with symptoms suggestive of RVF and delivered a baby weighing $3.2 \mathrm{~kg}$ with skin rash, palpable liver, and spleen. Two samples from the mother and neonate were screened and found to be positive for RVF-IgM (89). This case demonstrated that RVF can be vertically transmitted in human. A similar case was also reported before in Saudi Arabia, during the 2000 outbreak (90). These are consistent with the claims recently made about the burden of emerging zoonotic infectious disease among women in general and pregnant women, in particular (91).

Movement of animals during an outbreak can be a serious risk factor. Complete genome sequences from RVFV strains detected during the 2007 and 2010 outbreaks in Sudan suggested multiple introductions of RVFV into Sudan as part of sweeping epizootics from eastern Africa (8). All RVFV strains observed grouped into Kenya-1 or Kenya-2 sub lineages, which defined the eastern Africa outbreak in 2006-2008 (92). The sequencing also suggested that an earlier common ancestor from 1996 coinciding with the 1997-1998 outbreaks in the horn of Africa. The Kenya-2 sub lineage is now known to be widely distributed in Tanzania and Sudan $(8,92,93)$. The movement of animals from southern states in White Nile to northern ones in Gezira, Khartoum, and
Kassala for marketing was most likely responsible for the geographical expansion of the virus in central and eastern Sudan (Figure 2). Identical or nearly identical sequences of the virus strains were identified for different states and years, Khartoum in 2007 and Gezira in 2010, as well as Khartoum and West Nile in 2007. These sequences indicate recent movement of the virus in this region and support the necessity and utility of surveillance systems for recognizing when and where a large epidemic is imminent (8).

\section{SURVEILLANCE AND CONTROL OF RVF OUTBREAK: THE EXAMPLE OF SAUDI ARABIA IN 2000}

Saudi Arabia and Yemen experienced a huge RVF outbreak in the year $2000(29,30,54,55)$. It was the first outbreak in Middle East outside its endemic areas in Africa. The outbreak in Saudi Arabia is suggested to have been from eastern Africa by importation of infected animals (40), similar to the suggested route of introduction of RVFV into Egypt in 1977 from Sudan (94). The virus causing the Saudi Arabia outbreak belonged to the same strain that caused the 1997-1998 outbreaks in East Africa (95).

After the outbreak was declared, a team was established in collaboration between the Ministries of Health, Agriculture, and Water, and the Ministry of Municipalities and international organizations such as CDC, WHO, and National Institute of Virology, South Africa, to control the outbreak $(30,54,96)$. A strategy called "One Health" was then implemented by Saudi Arabia targeting 


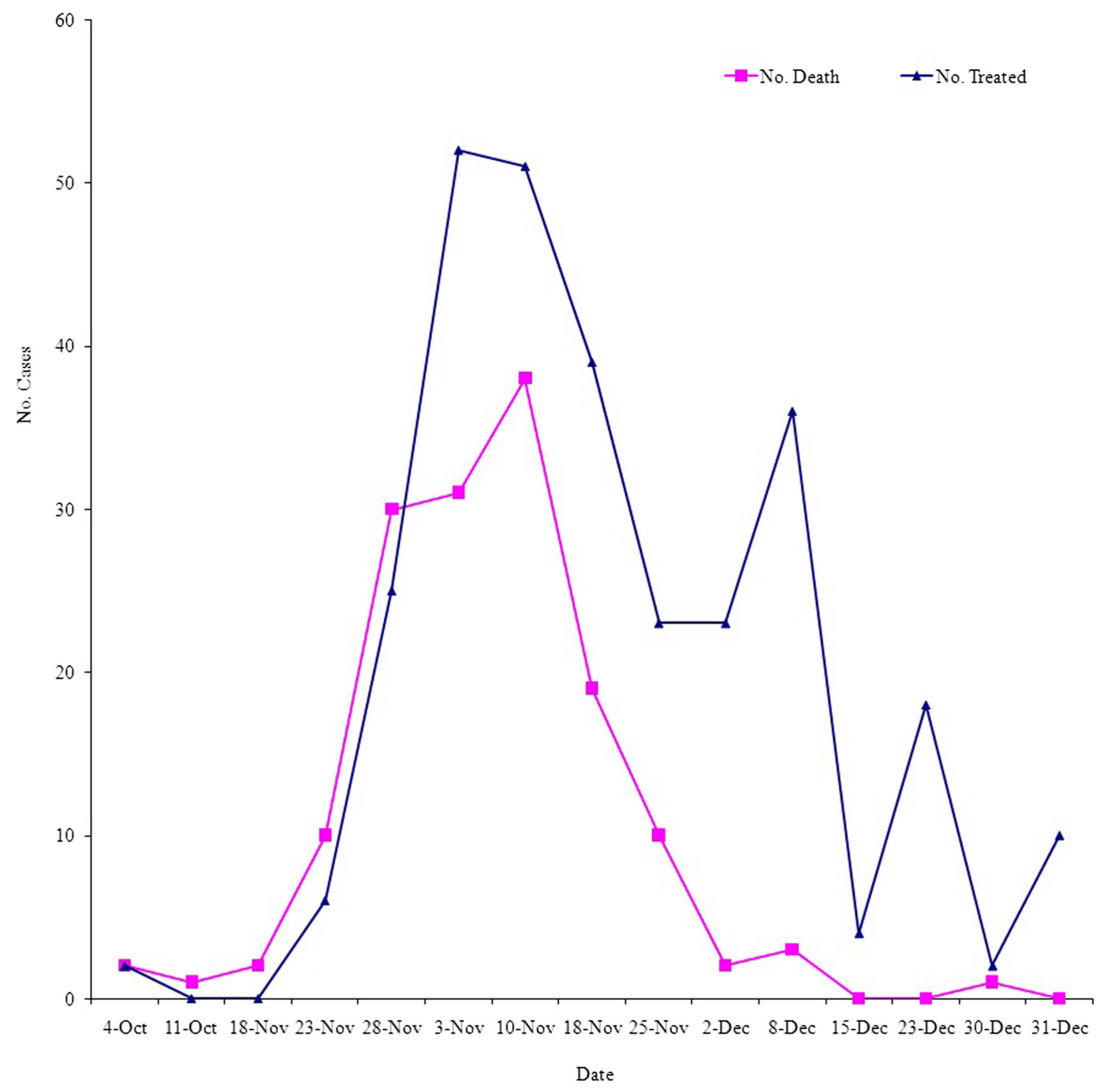

FIGURE 5 | Cases (No. received the treatment) and deaths from RVF over the period of the outbreak in Gezira State, Sudan, September-December 2007. Source: Epidemiology Unit, Ministry of Health, Gezira State.

both the animal and human hosts (17). The urgent integrated control measures that were implemented by this strategy during the outbreak included the following activities: (1) disposal of dead animals in an appropriate manner, (2) active surveillance surveys to detect cases of RVF among humans and animals to locate target areas for animal vaccination, and (3) apply a vaccination campaign that started in October $2000(16,30,31,54,96)$. Around $1,200,000$ doses of the vaccine were reported to be imported into Saudi Arabia and the campaign continued in 2001 with more than 10 million ruminants being vaccinated (31). These activities were accompanied by (4) a restriction on animal movements outside the affected areas and a ban on animal imports from RVF-enzootic countries (29). (5) For effective case management, detailed case definition was developed, training sessions on how to manage the suspected cases clinically was implemented, two well-prepared laboratories (one in the affected regions and the other in the capital of the country) for diagnosis of RVFV antibodies in suspected cases were also provided by the Saudi Ministry of Health $(29,54,96)$. (6) Epidemiological investigation was also performed to identify risk factors (30). (7) In addition, an entomological study to search for the mosquito breeding grounds (30) was followed by an intensive mosquito control program with spraying $(54,97)$. This strategy succeeded to limit the effect of the outbreak and curb the disease from spreading to other areas. Since 2000, only sporadic cases have been recorded in Saudi Arabia and only in the same regions where the original outbreak was reported (16). Later investigation on this strategy concluded that "One Health" approach is the best option to mitigate outbreaks of RVF. Collaboration between veterinary, health, and environmental authorities both at national and regional levels is needed to control RVF outbreak (17).

\section{CONCLUSION AND PERSPECTIVE}

From the foregoing narrative, we can conclude that RVF causes huge health and economic losses signified by the number of human 
deaths and high mortality and abortion rates in livestock. It is also clear that whereas RVF was previously restricted to specific areas in sub-Saharan Africa, the disease seems to be spreading into new territories beyond the traditional foci as evidenced by outbreaks in the Arabian Peninsula. The epidemiology of RVF is complex and transmission involves multiple mosquito vector species. A multiplicity of factors shapes the epidemiology of RVF. Key among these is rainfall and flooding, soil types, contact with animals, breeding sites, and availability and movement of livestock. Epizootics are interspaced with long periods of quiescence.

It is our considered view that repeated outbreaks could be forestalled with adequate sensitization of the policy makers. It is also clear that with enhanced coordination among stakeholders, e.g., Ministries of Health and Livestock, researchers, and local communities it is possible to better handle future outbreaks. Such coordination of stakeholders seems to have worked effectively in managing the outbreak in Saudi Arabia. Other regions such as eastern Africa that has borne the brunt of previous outbreaks should learn from the Saudi experience. In light of improved warning signs derived from satellite imagery and mapping, governments should come up with clear strategies and action plans for preparedness and handling of future outbreaks. Such strategies should include strong surveillance systems, adequate and well trained personnel, among others.

\section{AUTHOR CONTRIBUTIONS}

Yousif E. Himeidan suggested the topic, framed, drafted, and wrote up the manuscript. Mostafa M. Mahgoub collected the data on patients from Ministry of Health, Gezira State. Eliningaya J. Kweka, El Amin El Rayah, and Johnson O. Ouma drafted and reviewed the manuscript. All authors read and approved the final version.

\section{ACKNOWLEDGMENTS}

We thank the staff in the Epidemiology Unit, Ministry of Health, Gezira State for providing the data on patients of the 2007 outbreak.

\section{REFERENCES}

1. Daubney R, Hudson JR, Garnham PC. Enzootic hepatitis of Rift Valley fever: an undescribed virus disease of sheep, cattle and human from East Africa. J Pathol Bacteriol (1931) 34:545-79. doi:10.1002/path.1700340418

2. Stordy RJ. Mortality among lambs. Annual Report Department of Agriculture, British East Africa 1912-1913 (1913).

3. Davies FG. The historical and recent impact of Rift Valley fever in Africa. Am J Trop Med Hyg (2010) 83:73-4. doi:10.4269/ajtmh.2010.83s2a02

4. Ahmad K. More deaths from Rift Valley fever in Saudi Arabia and Yemen. Lancet (2000) 356:1422. doi:10.1016/S0140-6736(05)74068-X

5. World Health Organization. Outbreaks of Rift Valley fever in Kenya, Somalia, and United Republic of Tanzania, December 2006-April 2007. Wkly Epidemiol $\operatorname{Rec}(2007)$ 82:169-78.

6. Centers for Disease Control and Prevention. Rift Valley fever outbreak-Kenya, November 2006 - January 2007. MMWR Morb Mortal Wkly Rep (2007) 56:73-6.

7. Adam A, Karsany M, Adam I. Manifestations of severe Rift Valley fever in Sudan. Int J Infect Dis (2010) 14:179-80. doi:10.1016/j.ijid.2009.03.029

8. Aradaib IE, Erickson BR, Elageb RM, Khristova ML, Carroll SA, Elkhidir IM, et al. Rift Valley fever, Sudan, 2007 and 2010. Emerg Infect Dis (2013) 19(2):246-53. doi:10.3201/eid1902.120834
9. OIE Terrestrial Manual. Chapter 2.1.14. - Rift Valley fever. Version adopted by the World Assembly of Delegates of the OIE in May 2014 (2014). Available from: http://www.oie.int/fileadmin/Home/eng/Health_standards/tahm/ 2.01.14_RVF.pdf

10. Eisa M, Obeid HMA, El Sawi ASA. Rift Valley fever in the Sudan. Bull Anim Health Prod Afr (1977) 24:343-7.

11. Woods CW, Karpati AM, Grein T, McCarthy N, Gaturuku P, Muchiri E, et al. An outbreak of Rift Valley fever in Northeastern Kenya, 1997-98. Emerg Infect Dis (2002) 8:138-44. doi:10.3201/eid0802.010023

12. Jost CC, Nzietchueng S, Kihu S, Bett B, Njogu G, Swai ES, et al. Epidemiological assessment of the Rift Valley fever outbreak in Kenya and Tanzania in 2006 and 2007. Am J Trop Med Hyg (2010) 83:65-72. doi:10.4269/ajtmh.2010.090290

13. Dar O, McIntyre S, Hogarth S, Heymann D. Rift Valley feverand a new paradigm of research and development for zoonotic disease control. Emerg Infect Dis (2013) 19:18993. doi:10.3201/eid1902.120941

14. Rich KM, Wanyoike F. An assessment of the regional and national socioeconomic impacts of the 2007 Rift Valley fever outbreak in Kenya. Am J Trop Med Hyg (2010) 83:52-7. doi:10.4269/ajtmh.2010.09-0291

15. Little PD. Hidden Value on the Hoof: Cross-Border Livestock Trade in Eastern Africa. Common Market for Eastern and Southern Africa Comprehensive African Agriculture Development Program, Policy Brief Number 2, February 2009 (2009). Available from: http://www.caadp.net/pdf/COMESA\%20CAADP\% 20Policy\%20Brief\%202\%20Cross\%20Border\%20Livestock\%20Trade\%20(2). pdf

16. Al-Afaleq AI, Hussein MF. The status of Rift Valley fever in animals in Saudi Arabia: a mini review. Vector Borne Zoonotic Dis (2011) 11:1513-20. doi:10.1089/vbz.2010.0245

17. Hassan OA, Ahlm C, Evander M. A need for one health approach - lessons learned from outbreaks of Rift Valley fever in Saudi Arabia and Sudan. Infect Ecol Epidemiol (2014) 4:1-8. doi:10.3402/iee.v4.20710

18. Antonis AF, Kortekaas J, Kant J, Vloet RP, Vogel-Brink A, Stockhofe N, et al. Vertical transmission of Rift Valley fever virus without detectable maternal viremia. Vector Borne Zoonotic Dis (2013) 13(8):601-6. doi:10.1089/vbz.2012.1160

19. Acha P, Szyfres B. Zoonoses and Communicable Diseases Common to Man and Animals. (Vol. 2). Washington, DC: Pan American Health Organization/World Health Organization Scientific Publication (1987).

20. LaBeaud AD, Muchiri EM, Ndzovu M, Mwanje MT, Muiruri S. Interepidemic Rift Valley fever virus seropositivity, northeastern Kenya. Emerg Infect Dis (2005) 14:1240-6. doi:10.3201/eid1408.080082

21. Seufi AM, Galal FH. Role of Culex and Anopheles mosquito species as potential vectors of rift valley fever virus in Sudan outbreak, 2007. BMC Infect Dis (2010) 10:65. doi:10.1186/1471-2334-10-65

22. Easterday B, McGavran M, Rooney J, Murphy L. The pathogenesis of Rift Valley fever in lambs. Am J Vet Res (1962) 23:470-9.

23. Laughlin L, Meegan J, Strausbaugh L, Morens D, Watten R. Epidemic Rift Valley fever in Egypt: observations of the spectrum of human illness. Trans R Soc Trop Med Hyg (1979) 73:630-3. doi:10.1016/0035-9203(79)90006-3

24. Kahlon SS, Peters CJ, Leduc J, Muchiri EM, Muiruri S, Njenga MK, et al. Severe Rift Valley fever may present with a characteristic clinical syndrome. Am J Trop Med Hyg (2010) 82:371-5. doi:10.4269/ajtmh.2010.09-0669

25. Kebede S, Duales S, Yokouide A, Alemu W. Trends of major disease outbreaks in the African region, 2003-2007. East Afr J Public Health (2010) 7:20-9.

26. Clements AC, Pfeiffer DU, Martin V, Otte MJ. A Rift Valley fever atlas for Africa. Prev Vet Med (2007) 82:72-82. doi:10.1016/j.prevetmed.2007.05.006

27. Mohamed M, Mosha F, Mghamba J, Zaki SR, Shieh WJ, Paweska J, et al. Epidemiologic and clinical aspects of a Rift Valley fever outbreak in humans in Tanzania, 2007. Am J Trop Med Hyg (2010) 83:22-7. doi:10.4269/ajtmh.2010. 09-0318

28. Balkhy HH, Memish ZA. Rift Valley fever: an uninvited zoonosis in the Arabian Peninsula. Int J Antimicrob Agents (2003) 21:153-7. doi:10.1016/S09248579(02)00295-9

29. Saudi Ministry of Health; Department of Preventive Medicine and Field Epidemiology Training Program. Rift Valley fever outbreak, Saudi Arabia. Saudi Epidemiol Bull (2000) 8:1-8.

30. Centers for Disease Control and Prevention. Update: outbreak of Rift Valley fever-Saudi Arabia, August-November. MMWR Morb Mortal Wkly Rep (2000) 49:982-5. 
31. Elfadil AA, Hasab-Allah KA, Dafa-Allah OM. Factors associated with Rift Valley fever in South-West Saudi Arabia. Rev Sci Tech (2006) 25:1137-45.

32. World Health Organization. Report Update 5: Rift Valley Fever in Sudan. WHO Report (2008). Available from: http://www.who.int/csr/don/2008_01_22/en/

33. World Health Organization. Rift Valley fever fact sheet. Wkly Epidemiol Rec (2008) 83:17-24.

34. Balenghien T, Cardinale E, Chevalier V, Elissa N, Failloux AB, Jean Jose Nipomichene TN, et al. Towards a better understanding of Rift Valley fever epidemiology in the south-west of the Indian Ocean. Vet Res (2013) 44:78. doi:10.1186/1297-9716-44-78

35. Crabtree MB, Kent Crockett RJ, Bird BH, Nichol ST, Erickson BR, Biggerstaff BJ, et al. Infection and transmission of Rift Valley fever viruses lacking the NSs and/or NSm genes in mosquitoes: po tential role for NSm in mosquito infection. PLoS Negl Trop Dis (2012) 6:e1639. doi:10.1371/journal. pntd.0001639

36. O'Malley CM. Aedes vexans (Meigen): an old foe. Proceedings of the 77th Annual Meeting of New Jersey Mosquito Control Association New Brunswick, NJ: Mosquito Control Association (1990) p. 90-5.

37. Linthicum K, Davies F, Kairo A, Bailey C. Rift Valley fever virus (family Bunyaviridae, genus Phlebovirus). Isolations from Diptera collected during an inter-epizootic period in Kenya. J Hyg (Lond) (1985) 95:197-205. doi:10.1017/S0022172400062434

38. Lee VH. Isolation of viruses from field populations of Culicoides (Diptera: Ceratopogonidae) in Nigeria. J Med Entomol (1979) 16:76-9.

39. Fontenille D, Traore-Lamizana M, Diallo M, Thonnon J, Digoutte JP, Zeller HG. New vectors of Rift Valley fever in West Africa. Emerg Infect Dis (1998) 4:289-93. doi:10.3201/eid0402.980218

40. Miller B, Godsey M, Crabtee M, Savage H, Al-Mazrao Y, Al-Jeffri M. Isolation and genetic characterization of Rift Valley fever virus from Aedes vexans arabiensis, Kingdom of Saudi Arabia. Emerg Infect Dis (2002) 8:1492-4. doi:10.3201/eid0812.020194

41. Turell MJ, Linthicum KJ, Patrican LA, Davies FG, Kairo A, Bailey CL. Vector competence of selected African mosquito (Diptera: Culicidae) species for Rift Valley fever virus. J Med Entomol (2008) 45:102-8. doi:10.1603/00222585(2008)45[102:VCOSAM]2.0.CO;2

42. Sang R, Kioko E, Lutomiah J, Warigia M, Ochieng C, O'Guinn M, et al. Rift Valley fever virus epidemic in Kenya, 2006/2007: the entomologic investigations. Am J Trop Med Hyg (2010) 83:28-37. doi:10.4269/ajtmh.2010.09-0319

43. Hoch AL, Gargan TP II, Bailey CL. Mechanical transmission of Rift Valley fever virus by hematophagous Diptera. Am J Trop Med Hyg (1985) 34(1): 188-93.

44. Dohm DJ, Rowton ED, Lawyer PG, O’Guinn M, Turell MJ. Laboratory transmission of Rift Valley fever virus by Phlebotomus duboscqi, Phlebotomus papatasi, Phlebotomus sergenti, and Sergentomyia schwetzi (Diptera: Psychodidae). J Med Entomol (2000) 37(3):435-8. doi:10.1603/0022-2585(2000) 037[0435:LTORVF]2.0.CO;2

45. Ogoma SB, Lweitoijera DW, Ngonyani H, Furer B, Russell TL, Mukabana WR, et al. Screening mosquito house entry points as a potential method for integrated control of endophagic filariasis, arbovirus and malaria vectors. PLoS Negl Trop Dis (2010) 4:e773. doi:10.1371/journal.pntd.0000773

46. Logan TM, Linthicum KJ, Wagateh JN, Thande PC, Kamau CW, Roberts CR. Pretreatment of floodwater Aedes habitats (dambos) in Kenya with a sustainedrelease formulation of methoprene. J Am Mosq Control Assoc (1990) 6: 736-8.

47. Edwards FW. Mosquitoes of the Ethiopian Region III. Culicine Adults and Pupae. London: British Museum (Nat. Hist.) (1941).

48. White GB. Notes on a catalogue of Culicidae of the Ethiopian region. Mosq Syst (1975) 7:303-44.

49. Abdel Aziz M. Rift Valley fever: the story unfolds. J Public Health (2008) 3:5-10.

50. Faye O, Diallo M, Diop D, Bezeid O, Bâ H, Niang M, et al. Rift Valley fever outbreak with East-Central African virus lineage in Mauritania. Emerg Infect Dis (2003) 13:7. doi:10.3201/eid1307.061487

51. El-Akkad A. Rift Valley fever outbreak in Egypt, October-December 1977. J Egypt Public Health Assoc (1978) 53:123-8.

52. Meegan J, Hoogstraal H, Moussa M. An epizootic of Rift Valley fever in Egypt in 1977. Vet Rec (1979) 105:124-5. doi:10.1136/vr.105.6.124

53. Jupp P, Kemp A, Grobbelaar A, Lema P. The 2000 epidemic of Rift Valley fever in Saudi Arabia: mosquito vector studies. Med Vet Entomol (2002) 16:245-52. doi:10.1046/j.1365-2915.2002.00371.x
54. Centers for Disease Control and Prevention. Outbreak of Rift Valley fever Saudi Arabia, August-October. MMWR Morb Mortal Wkly Rep (2000) 49:905-8.

55. Centers for Disease Control and Prevention. Outbreak of Rift Valley fever, Yemen, August-October 2000. Wkly Epidemiol Rec (2000) 75(48):392-5.

56. Moutailler S, Krida G, Schaffner F, Vazeille M, Failloux AB. Potential vectors of Rift Valley fever virus in the Mediterranean region. Vector Borne Zoonotic Dis (2008) 8:749-53. doi:10.1089/vbz.2008.0009

57. Meegan JM, Khalil GM, Hoogstraal H, Adham FK. Experimental transmission and field isolation studies implicating Culex pipiens as a vector of Rift Valley fever virus in Egypt. Am J Trop Med Hyg (1980) 29:1405-10.

58. Jupp PG, Cornel AJ. Vector competence tests with Rift Valley fever virus and five South African species of mosquito. J Am Mosq Control Assoc (1988) 4:4-8.

59. Amraoui F, Krida G, Bouattour A, Rhim A, Daaboub J, Harrat Z, et al. Culexpipiens, an experimental efficient vector of West Nile and Rift Valley fever viruses in the Maghreb region. PLoS One (2012) 7:e36757. doi:10.1371/journal.pone. 0036757

60. Joubert JD, Ferguson AL, Gear J. Rift Valley fever in South Africa: 2. The occurrence of human cases in the Orange Free State, the north-western Cape province, the western and southern Transvaal. An epidemiological and clinical findings. S Afr Med J (1951) 25:890-1.

61. Meegan J, Bailey CL. Rift Valley fever. In: Monath TP, editor. The Arboviruses: Epidemiology and Ecology. Boca Raton: CRC Press, Inc. (1989). p. 51-76.

62. Abdel-Wahab KS, El Baz LM, El-Tayeb EM, Omar H, Ossman MA, Yasin W. Rift Valley fever virus infections in Egypt: pathological and virological findings in man. Trans R Soc Trop Med Hyg (1978) 72:392-6. doi:10.1016/0035-9203(78) 90134-7

63. Bird BH, Ksiazek TG, Nichol ST, MacLachlan NJ. Rift Valley fever virus. J Am Vet Med Assoc (2009) 234(7):883-93. doi:10.2460/javma.234.7.883

64. Morvan J, Fontenille D, Saluzzo JF, Coulanges P. Possible Rift Valley fever outbreak in man and cattle in Madagascar. Trans $R$ Soc Trop Med Hyg (1991) 85:108. doi:10.1016/0035-9203(91)90178-2

65. Morvan J, Saluzzo JF, Fontenille D, Rollin PE, Coulanges P. Rift Valley fever on the east coast of Madagascar. Res Virol (1991) 142:475-82. doi:10.1016/09232516(91)90070-J

66. Morvan J, Lesbordes JL, Rollin PE, Mouden JC, Roux J. First fatal human case of Rift Valley fever in Madagascar. Trans R Soc Trop Med Hyg (1992) 86:320. doi:10.1016/0035-9203(92)90329-B

67. Morvan J, Rollin PE, Laventure S, Rakotoarivony I, Roux J. Rift Valley fever epizootic in the central highlands of Madagascar. Res Virol (1992) 143:407-15. doi:10.1016/S0923-2516(06)80134-2

68. Sindato C, Karimuribo ED, Pfeiffer DU, Mboera LE, Kivaria F, Dautu G, et al. Spatial and temporal pattern of Rift Valley fever outbreaks in Tanzania; 1930 to 2007. PLoS One (2014) 9(2):e88897. doi:10.1371/journal.pone.0088897

69. Anyamba A, Chretien JP, Small J, Tucker CJ, Formenty PB, Richardson JH, et al. Prediction of a Rift Valley fever outbreak. Proc Natl Acad Sci U S A (2009) 106:955-9. doi:10.1073/pnas.0806490106

70. Nguku PM, Sharif SK, Mutonga D, Amwayi S, Omolo J, Mohammed O, et al. An investigation of a major outbreak of Rift Valley fever in Kenya: 2006-2007. Am J Trop Med Hyg (2010) 83:5-13. doi:10.4269/ajtmh.2010.09-0288

71. Murithi RM, Munyua P, Ithondeka PM, Macharia JM, Hightower A, Luman ET, et al. Rift Valley fever in Kenya: history of epizootics and identification of vulnerable districts. Emerg Infect Dis (2010) 18:1-9. doi:10.1017/ S0950268810001020

72. Hightower A, Kinkade C, Nguku PM, Anyangu A, Mutonga D, Omolo J, et al. Relationship of climate, geography, and geology to the incidence of Rift Valley fever in Kenya during the 2006-2007 outbreak. Am J Trop Med Hyg (2012) 86(2):373-80. doi:10.4269/ajtmh.2012.11-0450

73. Fontenille D, Traore-Lamizana M, Zeller H, Mondo M, Diallo M, Digoutte JP. Short report: Rift Valley fever in western Africa: isolations from Aedes mosquitoes during an interepizootics period. Am J Trop Med Hyg (1995) 52: 403-4.

74. Mondet B, Diaïté A, Ndione JA, Fall AG, Chevalier V, Lancelot R, et al. Rainfall patterns and population dynamics of Aedes (Aedimorphus) vexans arabiensis, Patton 1905 (Diptera: Culicidae), a potential vector of Rift Valley fever virus in Senegal. J Vector Ecol (2005) 30:102-6.

75. Logan TM, Linthicum KJ, Thande PC, Wagateh JN, Nelson GO, Roberts CR. Egg hatching of Aedes mosquitoes during successive floodings in a Rift Valley fever endemic area in Kenya. J Am Mosq Control Assoc (1991) 7(1):109-12. 
76. Anyamba A, Linthicum KJ, Small J, Britch SC, Pak E, de La Rocque S, et al. Prediction, assessment of the Rift Valley fever activity in East and Southern Africa 2006-2008 and possible vector control strategies. Am J Trop Med Hyg (2010) 83:43-51. doi:10.4269/ajtmh.2010.09-0289

77. Moszynski P. Flooding worsens in Sudan. BMJ (2007) 335:175. doi:10.1136/ bmj.39283.476644.DB

78. El Imam M, El Sabiq M, Omran M, Abdalkareem A, El Gaili MMA, Elbashir A, et al. Acute renal failure associated with the Rift Valley fever: a single center study. Saudi J Kidney Dis Transpl (2009) 20:1047-52.

79. World Health Organization. Report Update: Rift Valley Fever in Sudan. WHO Report (2007). Available from: http://www.who.int/csr/don/2007_11_07/en/

80. Garang GD. A Press Release on Rift Valley Fever Disease in Sudan 10/11/2007. Khartoum: Federal Ministry of Animal Resources and Fisheries (2007).

81. Hassan OA, Ahlm C, Sang R, Evander M. The 2007 Rift Valley fever outbreak in Sudan. PLoS Negl Trop Dis (2011) 5(9):e1229. doi:10.1371/journal.pntd. 0001229

82. Anyamba A, Linthicum KJ, Small JL, Collins KM, Tucker CJ, Pak EW, et al. Climate teleconnections and recent patterns of human and animal disease outbreaks. PLoS Negl Trop Dis (2012) 6(1):e1465. doi:10.1371/journal.pntd. 0001465

83. Linthicum KJ, Anyamba A, Tucker CJ, Kelley PW, Myers MF, Peters CJ. Climate and satellite indicators to forecast Rift Valley fever epidemics in Kenya. Science (1999) 285(5426):397-400. doi:10.1126/science.285.5426.397

84. Abdo-Salem S, Gerbier G, Bonnet P, Al-Qadasi M, Tran A, Thiry E, et al. Descriptive and spatial epidemiology of Rift Valley fever outbreak in Yemen 2000-2001. Ann N Y Acad Sci (2006) 1081:240-2. doi:10.1196/annals.1373.028

85. Eisa M, Kheir el-Sid ED, Shomein AM, Meegan JM. An outbreak of Rift Valley fever in the Sudan - 1976. Trans R Soc Trop Med Hyg (1980) 74:417-9. doi:10.1016/0035-9203(80)90122-4

86. Gubler DJ. The global emergence/resurgence of arboviral diseases as public health problems. Arch Med Res (2002) 33(4):330-42. doi:10.1016/S01884409(02)00378-8

87. Pfeffer M, Dobler G. Emergence of zoonotic arboviruses by animal trade and migration. Parasit Vectors (2010) 3:35. doi:10.1186/1756-3305-3-35

88. Hassanain AM, Noureldien W, Karsany MS, Saeed NS, Aradaib IE, Adam I. Rift Valley fever among febrile patients at New Halfa hospital, eastern Sudan. Virol $J$ (2010) 7:97. doi:10.1186/1743-422X-7-97

89. Adam I, Karsany MS. Case report: Rift Valley fever with vertical transmission in a pregnant Sudanese woman. J Med Virol (2008) 80:929. doi:10.1002/jmv.21132

90. Arishi HM, Aqeel AY, Al Hazmi MM. Vertical transmission of fatal Rift Valley fever in a newborn. Ann Trop Paediatr (2006) 26:251-3. doi:10.1179/ 146532806 X120363
91. Theiler RN, Rasmussen SA, Treadwell TA, Jamieson DJ. Emerging and zoonotic infections in women. Infect Dis Clin North Am (2008) 22:755-772,vii-viii. doi:10.1016/j.idc.2008.05.007

92. Bird BH, Githinji JW, Macharia JM, Kasiiti JL, Muriithi RM, Gacheru SG, et al. Multiple virus lineages sharing recent common ancestry were associated with a large Rift Valley fever outbreak among livestock in Kenya during 2006-2007. J Virol (2008) 82:11152-66. doi:10.1128/JVI.01519-08

93. Carroll SA, Reynes JM, Khristova ML, Andriamandimby SF, Rollin PE, Nichol ST. Genetic evidence for Rift Valley fever outbreaks in Madagascar resulting from virus introductions from the east African mainland rather than enzootic maintenance. J Virol (2011) 85:6162-7. doi:10.1128/JVI.00335-11

94. Gad AM, Feinsod FM, Allam IH, Eisa M, Hassan AN, Soliman BA, et al. A possible route for the introduction of Rift Valley fever virus into Egypt during 1977. Am J Trop Med Hyg (1986) 89:233-6.

95. Shoemaker T, Boulianne C, Vincent MJ, Pezzanite L, Al-Qahtani MM, AlMazrou Y, et al. Genetic analysis of viruses associated with emergence of Rift Valley fever in Saudi Arabia and Yemen, 2000-01. Emerg Infect Dis (2002) 8:1415-20. doi:10.3201/eid0812.020195

96. World Health Organization. 2000 - Rift Valley fever in Saudi Arabia Update/Acute Haemorrhagic fever Syndrome in Yemen - Update, 29 September 2000 (2000). Available from: http://www.who.int/csr/don/2000_09_29/en/

97. Shimshony A, Economides P. Disease prevention and preparedness for animal health in the Middle East. Rev Sci Tech (2006) 25:253-69.

Conflict of Interest Statement: The authors declare that the research was conducted in the absence of any commercial or financial relationships that could be construed as a potential conflict of interest.

Received: 29 July 2014; accepted: 16 September 2014; published online: 06 October 2014.

Citation: Himeidan YE, Kweka EJ, Mahgoub MM, El Rayah EA and Ouma JO (2014) Recent outbreaks of Rift Valley fever in East Africa and the Middle East. Front. Public Health 2:169. doi: 10.3389/fpubh.2014.00169

This article was submitted to Epidemiology, a section of the journal Frontiers in Public Health.

Copyright (c) 2014 Himeidan, Kweka, Mahgoub, El Rayah and Ouma. This is an openaccess article distributed under the terms of the Creative Commons Attribution License (CC BY). The use, distribution or reproduction in other forums is permitted, provided the original author(s) or licensor are credited and that the original publication in this journal is cited, in accordance with accepted academic practice. No use, distribution or reproduction is permitted which does not comply with these terms. 